\title{
The Application of Effect Rules at Establishing Jurisdiction by US Courts and Enlightenments to People's Courts in PRC
}

\author{
Kaixuan Gong ${ }^{1}$ \\ ${ }^{1}$ Zhong Nan University of Economics and Law, China \\ Correspondence: Kaixuan Gong, Zhong Nan University of Economics and Law, China. E-mail: \\ crackingtoefl@qq.com
}

Received: April 29, 2014 Accepted: May 11, 2014 Online Published: June 4, 2014

doi:10.5430/sass.v1n2p57 URL: http://dx.doi.org/10.5430/sass.v1n2p57

\begin{abstract}
Since 1984, the case Jones v. Calder was brought to Supreme Court, and the plaintiff had successfully convinced the Supreme Court that the California district court, based on the effect caused by the out-of-state defendant, is competent to exercise jurisdiction over the case. From the insight of Supreme judges, although the defendant is not within the territory of California, the effect resulted from the Florida defendant's defamation to the California is constituted as the "Minimum contacts". And also, such intentional effect did not contradict the traditional "notion of fair play and substance justice". When it comes to the contacts with the forum state, it is hold by the Supreme Court that the Florida defendant is expected to be sued at California for the reason that the action taken by defendant is aimed to striking plaintiff's career and vilifying her reputation. Put it in another way, the effects occurred in California by defendant's actions were within defendant's expectations, and it is also expected that the defendant had expected to be sued at the plaintiff's forum state. The import of establishing effect-test is to redress aggrieved parties as soon as possible. Since effect-test had been introduced in tort cases, to a great extent, this test provide guidance for judges to exercise jurisdiction to the out-of- state conduct by non-resident. However, it has to mention that the application, especially in the era of Internet, seems to be various. With the explosive growth of e-commerce trades and frequent communication through Internet, effect-test had been invited into the e-commerce world by federal judges to decide jurisdiction to cases like intellectual property infringement, defamations out of the state. When taking effect-test, courts focus on the facts presented in the case to satisfy the "the minimum contacts" with the forum state. But cases alike were concluded with different decisions. So the diverse decisions based on similar facts inspire me to explore what drives the judges to apply effect-test? The article maintains that a certain merit lays a solid foundation for the decisions made by federal courts. And also confirms that overall interest of the forum state is considered by the federal courts to apply effect-test. Further, it is the overall interest of the forum state that promotes the federal courts to manipulate effect-test to decide the competence to a certain case, since in such case, some purely subjective facts allow room for a large amount of discretion of judges.
\end{abstract}

Keyword: calder-effect, jurisdiction, merit, logics

\section{Introduction}

In 1984, the groundbreaking case Calder v. Jones lay a foundation for the formation of effect-test that is then applied by federal courts to analyze jurisdiction in tort cases in which a non-resident commit a tort outside the forum state. The effect, including harm or other losses, caused by tort which is committed outside the forum state may constitute the "Minim Contact" which is indispensable if a court wished to exert jurisdiction over a case in which the defendant is an out of state resident. In this precedent, a Hollywood star, shelly Jones, who was a resident of California, sued a Florida magazine for vilifying her reputation at California District court. The plaintiff argues that the defamation conducted by defendant caused not only to her psychological distress but also catastrophe to her career at California, the effect of defamation is obvious. However, considering the fact that defendant was located at Florida, and actually had no contacts with California, it is understandable that the defendant would challenge the jurisdiction of California District court for the Minimum contacts the defendant with California. Finally, this case went to Supreme Court, and judges at Supreme Court supported the jurisdiction of California district court. The Supreme Court believes that a resident inflicted by out-of-state actors can be redressed at a convenient forum state of his/her residence. The state 
which an aggrieved part resided in has a general interest to provide protection for him/her. In this case, for the damage suffered by the California resident, the jurisdiction hold by California Court did not betray the traditional doctrine of fair play and substance justice. The relief provided by the state is within the doctrine. Subsequently, the test considering effect occurred in the forum state was widely applied by federal courts to tort cases. Until the 21th century, the age of Internet sprawling around the world, effect-test is favored by courts to deal with jurisdiction concerning complicated Internet tort cases. It is no exaggeration to judge that effect-test still obviously remains one of the dominant methods to analyze a court's jurisdiction. However, unification of applying this test seems to be unsatisfying, even perplexing. It may notice that some cases concerning the application of effect-test deviate from the doctrine of this method establishing by Supreme Court, even more, the test was manipulated by some federal courts to grab jurisdiction to a case, since the facts, especially in Internet tort cases, can be recognized in different ways to satisfy effect-test based on judges' opinions. So, it is necessary to unveil the guidance of federal courts to apply this test.

\section{The Logic of Applying Effect-test}

After Calder, it has been concluded that three elements should be satisfied if a case is applied effect-test to analyze jurisdiction. The first one is that a defendant intentionally commits torts. Secondly, conducts committed by defendant should be aimed at the forum state in which plaintiff resides. Thirdly, defendant is likely to know the injury caused by his/her conducts would inflict plaintiff.

\subsection{Purposeful Direction}

It should note that purposeful direction is distinct from purposefully avails itself of the privilege of conducting activities in the cases of contract. The former usually serve as an indication of conducts occurred in a certain tort case. It refers that an out-of-state defendant commits a tort towards a plaintiff residing in a forum state. One apt example is the circulation of a magazine in several states, and someone who lives outside of the forum state published the defamation article to someone residing in the forum state. If some conducts, occurred occasionally instead of on purpose, caused injuries to someone, it is certain that a court can not claim its jurisdiction to a case based on effect-test. And also, this element excludes the circumstances involving contract, since effect-test is used to analyze the competence of a court to a tort case.

\subsection{Conducts Expressly Aimed at Forum State}

The second one is the formal element to judge the jurisdiction based on effect-test. If the jurisdiction in a certain case cannot meet such formal requirement, the competence of a court to a certain case will violate due process clause. Consequently, the element will be applied to judge the rationality of the jurisdiction in a case. However, this element is a subjective to a great extent, which depends on the recognition of judges to facts in a case. It is generally to observe federal courts to take the following ways to evaluate the aim of conducts. First of all, the most frequent method, the medium utilized by a defendant to commit conducts is highly valued by judges to judge its aim. Under the background of prevalent traditional mediums, such as newspaper and magazines, judges will consider the main place in which a newspaper or a magazine issued and the major readers of a newspaper and a magazine. The facts taken by judges will reflect the aim of a defendant. This method is persuasive and reliable. However, in the era of Internet, the judgments of the aim of conducts committed through Internet will be tricky. Some scholars advise that evaluating the content of a website, the register, or even the advertisements on the website can judge the readers to whom the website is aimed at. But this method will not work when a website is open for the whole country, even to the world. The second method is that doers know the residence of a plaintiff to whom his/her conducts is aimed at or the main business place. A doer intends to exert effect by his/her conduct. It is certain that he/she intends to cause the effect in the state in which he/she resides. In Calder, it was illustrated by federal courts that it was the effects caused by the defamation that generated the losses in the forum state. The aim of the defendant's defamation is to engender negative consequences in the forum state. It is reasonable to conclude that if a defendant wished to cause effect in the forum state, he/she must know the place in which the conduct-pointed plaintiff resided. This conclusion significantly matters with the "minim contact" that the defendant with the forum state. The third method is to measure the motive of a defendant. In some cases, some conducts committed by defendants are aimed to raise economic benefits. It is a widespread way that courts consider the motive of the main conduct in combination of subsequent conducts served for the motive to assess the explicit direction.

\subsection{The Harm Caused by Conducts}

In the context of torts, the harm is usually referred to something bad that has already taken place by federal courts. 
But in some situations, courts may take the potential harm that a conduct may cause into consideration in order to be competent to a case. This article hold that harm element play an indispensable role when courts apply effect-test, and also this element can be referred as substance element, compared with formal element. The unbalanced interests caused by harm at the forum state make it justifiable that even though the defendant is a nonresident of the forum state, it can be predicted by the nonresident that he/she will be sued at the forum state for the intentional acts. Harm taken placed at the forum state means that the original form of interests protected by a state is devastated by the conducts. Consequently, in order to redress such form to the original, the forum of the state enjoys the interests to hold jurisdiction for the case, which can be reflected by the argument of Supreme Court.

\subsection{Conclusion}

It is argued that when courts are inclined to apply effect-test, a hidden presupposition of the application considered by the courts is to evaluate the harm caused by the conducts. Provided no harm caused by the conducts, it is natural that the forum of a state has no interests to adjudicate a case, otherwise, courts will betray the doctrine of due process clause. After preliminary evaluation of harm, courts will compare the aggrieved interests with other interests, such as the whole interest of the forum state, and then, in conjunction with the formal element-the direction of conducts, decide whether to exercise jurisdiction to a case. From what has been stated above is the logic when a court apply effect-test. But, it has to be noted that, in some cases, courts have decided whether to exercise jurisdiction or not once after harm evaluation. In some absurd situations, courts will manipulate formal element to attain theirs targets since substance element cannot lay a sound foundation for applying effect-test. One of absurd situation can be aptly exemplified by Schwarzengger v. Fred Martin Motor Co. In this case, the arguments stated by the judges of Ninth Circuit court are tendentious, which can be conceived as severely department from the original intention of effect-test.

\section{Comparison and Analysis of Cases in Similar Facts to Unveil Hidden Merits Guiding Courts to Apply Effect-test}

What guide courts to apply effect-test when cases involving similar facts? One scholar has made a perspicacious argument concluded from different cases that indicates that when a court applies effect-test, he doubted that whether the application of effect-test is based on the original purposes and principles established by Calder case or courts have taken other factors into consideration. In this context, the application of effect-test will be complicated severely. The following cases will reveal the hidden merits.

\subsection{Calder v. Jones and Young v. New Haven Advocate}

In Calder, the facts has been discussed above, I have to mention that the editors and authors believe that the court is not competent to exercise jurisdiction over them. They defended that although a large number of national magazine were published in California which leaded to the reasonableness of minimum contact between the magazine and California, it cannot be concluded that their contacts with California were established. Meanwhile, editors and authors also noted that they did not work in California, they have ever travelled to California only one time, which is unrelated with the publication and distribution of the articles. When it comes to the constitutional rights of citizens, their freedom of speech were protected by the Constitution. Therefore, the editors and authors claimed that their conducts were with the sphere of speech freedom, and consequently, the California court should not exercise jurisdiction on this case. But the court held that the tort committed by editors and authors is aimed at the California resident, and the plaintiff has suffered huge material losses and mental damages. California district court has the interest to provide redress for the aggrieved part who was a resident of California. Regarding to the provisions of First Amendment freedom of speech, the California Court refused to consider it when measuring its jurisdiction. Accordingly, the Court considered that it is in the procedural stage to determine whether the competence of jurisdiction of the court to the case. So it was unnecessary to think of the content of the First Amendment which had been specified in substantive laws which would be applied in the later process.

However, in the case, Young v. New Haven Advocate, which is similar to Calder, the court in this case had come to completely different conclusions. In this case, Connecticut State had signed an agreement with Virginia concerning prisoners transfer. Several newspapers located at Connecticut quoted a number of articles to question the rationality of such agreement on their websites, which included defamation of a Virginia prison guards Stantely - Young, languages such as " Young retains a lot of the American Civil War Confederate souvenirs, he arranged the office enough to make people think he is a racist, " "Young's Confederate memorabilia in the office place, feels like a Civil War Confederate victory." Yang believed that these statements vilified his reputation. Therefore, he filed a lawsuit at 
the district court in Virginia. The case went to the Forth Circuit Court. The court conclude that, under the effect-test, the Virginia district court cannot exercise jurisdiction in this case for the reason that although the newspaper located at Connecticut State published articles on its website and the residents of Virginian residents could read the article through Internet, intentions of publishing such articles were to promote the discussion of the rationality of the agreement instead of aiming at causing harm to the warden. Since the effect-test require conducts clearly aimed at forum state, the conducts of publicizing articles by Connecticut cannot meet the requirement of effect-test. For this reason, the Virginia district court cannot exercise jurisdiction.

By comparing these two cases, it can be found that the courts have made an assumptions about parties' conducts when applying effect-test, namely whether the conducts of the parties are infringement and non- legitimacy. The nature of the conduct of the parties recognized by Court actually determined whether the court would exercise jurisdiction. When it comes to the nature of the conducts of parties, the interests of forum state will be involved in evaluation by Court. In Calder, the Court seek to protect the interests of the aggrieved part who was a resident of California, and this aggrieved party would obtain adequate relief when subjected under the jurisdiction of California district court. From the language used by the court to illustrate reasonableness of its jurisdiction pretended a critical tone against the editor and authors which can be conceived as the conducts committed the defendants are infringement and non- legitimacy assessed by Court. For example, "the plaintiff had suffered tremendous damage", "the defendants knew the consequences of their actions might bring to the plaintiff," "plaintiff had suffered huge trauma", "the plaintiff's reputation and career had been vilified." But in Young, it can be inferred from the statements of Fourth Circuit Court that conducts committed by defendants are not actually conceived as illegality and infringement. The tone used by court in describing the conducts of the defendant's case is much gentler than that of in the Calder. For example, "The defendant only are in the discussion of the harsh conditions of Virginia prison ", "just questioned about the transfer of prisoners to Virginia", "concern about Confederate memorabilia kept by the plaintiff." Based on the presupposition that the defendant's conducts are not treated as illegality and infringement, the court accepted the claims provided by defendants. Subsequently, the court reasoned that, under the effect-test, the publicity of articles were not expressly aimed at the Virginia warden. Consequently, the jurisdiction of Virginia district is not tenable. One fact in Young has observed by the author-the recognition of the intention of defendant' conducts. Although the Fourth Circuit court held that the defendant's conduct did not clearly point to Virginia, under the premise of the Internet without borders, to judge the intention of publishing articles and the intended readers are purely subjective. Through the Internet, Virginia residents can read those articles too. It can hardly to conclude that the effect caused by publishing articles by Connecticut newspaper does not make a difference in Virginia. To some degree, more or less, the reputation and impression of the warden have been affected by the articles. But for the reason for the adoption of the court's such subjective judgment, the fundamental reason lies in the overall interest of the state courts to measure and consider. First, the facts of the Young case display that the plaintiff had not suffered great losses due to the publication of the articles on the defendants' websites. Furthermore, the plaintiff-the Virginia warden's work and life had not experiencing fluctuations and great tribulations. Secondly, the plaintiff had admitted that, in his office, a large number of Confederate memorabilia were placed, which might give a hint that such behavior under public office can arise the suspect that the warden's thoughts is entangled with race inclination, ethical issues and other moral problems. To observe this issue on a higher level, it can be assumed that if Virginia is competent to this case, which may bring about undesirable consequences. In detail, applying effect-test, that the conduct of defendant should be deemed as tort can only justify the jurisdiction of Virginia. Thus, in a indirect way, the court has acknowledged the legitimacy of the plaintiff' behavior. A controversial legal issues are likely to rise the undesired tension between the Connecticut state and the Virginia state, which were in different camps in civil war. The court would preclude the undesirable results in the first place.

The above two cases are analyzed with respect to the dispute involving the defamation and under such condition, how courts apply effect rules. In the next, sharing similar facts, two typical cases involving commercial interests will be discussed. In these two cases, an alleged infringement were inspected by courts to whether establish its jurisdiction to the case under effect-test.

\subsection{Ubid. Inc V. GoDaddy and Imageline, Inc V. Fotalia, LLC}

In the case Ubid. Inc V. GoDaddy, the plaintiff Ubid, which was located at Illinois, was a company majorly engaged in auction of leftovers. Defendant GoDaddy Group largely worked on the register of website domain. For the reason that the defendant allows its clients to register a domain which was similar to the plaintiff's and thus such conduct was conceived by the plaintiff as a violation of the anti- cybersquatting Consumer Protection Act, a suit concerning illegal registration had been filed to the District Court of Illinois by the plaintiff. The Court upheld the defendant's assertion of jurisdiction, justified the defense and dismissed the plaintiff's claim. The court's argument lied in the 
reason that the defendant's contact with Illinois apropos only two registered domain names of Illinoi, and this connection to Illinois residents was unilaterally created by the residents of Illinois through the websites owned by defendant. What defendant had done was to receive information passively from the two residents of Illinois. At the same level, the conduct committed by the defendant not expressly intended to cause effect in the Illinois as well as did not aware the harm may suffered by the plaintiff. It could be inferred that jurisdiction originated from effect-test is untenable. However, when this case went to seventh circuit, things came to be totally different. The Seventh Circuit Court rejected the defendant's defense and revoked the decision made by Illinois district court. It was held by the Seventh Circuit Court that, according to the facts, defendant earned millions of dollars from Illinois, owned thousands of employees, spent a large amount of money on advertisements, and also had millions of potential customers. Therefore, it could be concluded that the defendant had successfully opened the markets at Illinois, whose effluence at Illinois is self-evident. According to facts and conclusions listed above, the defense claimed by the defendant could not justify itself merely based on the reason that the conduct did not point to Illinois directly as well as did not know that the plaintiff would suffer losses. In this case, although the decision of not being competent to case made by the Illinois district court was rejected by the Seventh Circuit Court, it can safely obtain the conclusion that no matter the District Court of Illinois or the Seventh Circuit Court analyzed the jurisdiction at the evaluation of the interests of the forum state when applied effect-test. However, the only difference is the starting point of the evaluation of the interests when the two analyze the jurisdiction. It is overt that the Illinois District Court focused on the local interests which is linked with domain registers at Illinois conceived as the contact with the forum state. The analysis of interests lay a foundation for the application of effect-test, to be more specific, the ignorant consideration of the overall interests of the forum state leads to the conclusion that the conduct made by the defendant was not expressly aimed at the forum state. Therefore, the requirements of effect-test cannot be met. On the contrary, standing at a high level, the Seventh Circuit made the evaluation by considering the facts of the commercial activities conducted by the defendant, also in conjunction with the overall interests of the forum state. Although contacts between the defendant and the forum were only two register domain names at Illinois, according to the overall influence at the forum state of the defendant, it can be drew that the defendant's conducts express obvious direction, which may also cause harm to other corporations at the forum state.

While in an another case, Imageline, Inc V. Fotalia, LLC, the plaintiff Imageline, an based company filed a suit at North Georgia district court against the defendant which was located at Virginia for the infringement of intellectual property. The defendant replicated and spread the original data analysis deriving from the plaintiff's websites without its agreement. In this situation, the defendant demure to the competence of North Georgia Court to the case by applying effect-test. The district court ultimately upheld the defendant's claim, declining to exercise jurisdiction over the case. The main reason was stated by the court that the defendant's principal place of business was in New York. Among all 0.17 million registers of the website owned by the defendant, the registers who were residents of Georgia accounted for only $1.9 \%$. In the mere number of $1.9 \%$, only one account maintained an active status. However, the Georgia register did not download any of the alleged original data analysis may conceived as infringement. It could be understandable that the infringement caused by the defendant may result in damage in Virginia, but the actual harm did not occur at the Georgia state which cannot reach the requirement of effect-test, leading to the conclusion that the Georgia court was not competent to the case. Reviewing the perspective where the district to analysis its competence to the jurisdiction, the author perceives that the district court paid a great attention to the commercial interests with the forum state, when applying the effect-test. The non-entangled commercial interest between the defendant and the forum state dominated the application of effect-test by the court. To be more specific, the court attached a greater importance to the harm or potential one by the infringement at the forum state than the expressly direction of such infringement. This argument can be aptly illustrated by the grounds made by the court. Combing with the consideration of no significant commercial connection with the forum state with no harm been caused by such infringement, the district declined to take jurisdiction to this case.

From what has been discussed above, the cases, apropos intensively with commercial interests, courts take the overall interests of the forum state as the priority to consider the application of effect-test. It is undisputable that courts to evaluate the interests of the forum state when applying effect rules since such test is deeply involved with diverse interests.

\section{Enlightenments from Effect Rules on Jurisdiction Rules of China}

Despite the fact that the effect rules have gained affirmations from judicial practices of America, whether the same rules can be grafted to jurisdiction rules of China shall be regarded and treated with different conditions. As for cases 
taking place domestically (excluding cases involving Hong Kong, Macao and Taiwan, such divisions made by the author are made according to different legal fields), if the doer conducts infringing acts against the victim beyond the residential area of the victim (area beyond the judicial scope governed by the basic court), effect rules in this case cannot be introduced. Since the effect rules are generated within the American jurisdiction rules featured with strict regionalism, their corresponding governing practices with the benefits of local courts with their value guidance are not suitable for our environment formed by our own jurisdiction rules of China. In addition, more than 20 years' experience has been accumulated within American jurisdiction practices for the effect rules, legal precedents out of large quantity of variety of cases have been deposited, together with traditions in following earlier precedents, American courts show relatively more proficiencies in handling jurisdiction issues with adoption of effect rules. Besides, comprehensive judicial system and judges with higher business qualities have both contributed in preventing the courts from taking advantage of effect rules in depriving cases or rejecting their jurisdictions towards cases, what's more important is, applicable effect rules for the courts makes sure the minimum connection cannot surpass the red lines established by standard procedures and terms of the Constitution. With insurance and promotion from the Constitution, effect rules are possible to play their rules completely within their own fields. Looking throughout jurisdiction rules of China, there are remarkable differences between our jurisdiction system with "plaintiff against defendant" as the leading factor and the jurisdiction system of America with "sovereignty of states" and "minimum connections" as its framework, such rules born and grown in a foreign land seem difficult to find their base in our jurisdiction environment. Further, there is large flexibility in application of such effect rules, to access and balance the benefits of regions where the courts sit and the other benefits is a technical tough issue, due to incomplete business qualities and superficial theoretical foundations of local judges from those basic courts of our country, difficulties will pop up when similar issues are under processing, the final result will be presented in such a presentation that local courts utilizes such effect rules to fight for or reject jurisdiction of cases. As the proverb goes, "Oranges grown in Huainan are called oranges, grown in Huaibei are whereas called trifoliate oranges", in case mechanical application of the effect rules, consequences triggered by such "trifoliate oranges turned oranges" will be hard to avoid.

As for cases involving foreign interest(including cases involving Hong Kong, Macao and Taiwan), in case the doer conducts infringement behaviors against Chinese citizens outside of China, the author purports that the People's Court may introduce such effect rules into these cases to deal with jurisdiction issues. From the above stated analyses, the initial mission for American court application effect rules against assertion of jurisdiction of cases is to supply timely, sufficient and convenient remedies for the victims. In case resident inside China gets attacked by infringement acts outside of China, the People's Court would reject to perform its jurisdiction with such explanations as such infringement did not take place in China or the actor of such infringement does not possess any residence in China, the victim would probably encounter such an awkward situation with nowhere to sue his/her files. Under such circumstance, if the victim has to institute legal proceedings from an instant foreign country, it could turn worse from bad. Because of totally strange environment, worsened by language barrier and unfamiliarity to foreign laws, the victim could possibly face unfavorable situation in foreign suits. It is doubtful whether the justice asserted by the victim has been supported even if he/she wins such suit based on the fact that large quantity of man power and money have been expended and the victim has suffered a lot and exhausted from such case. With popularity of internet over the entire world, international internet infringement has become more and more rampant due to fast and convenient streaming of information. Under such a background, based on the essentials of effect rules, the author holds such an idea that it is viable for the People's Court to use applicable effect rules to handle jurisdiction issues. Firstly, Supreme People's Court may select basic courts in the eastern costal area with more openness as pilot region, collect and summarize from experiences with respect to compatibility between local People's Courts and such rules, then propagate those experiences towards the other areas, cases handled through jurisdiction performance with applicable effect rules for local People's Court shall be filed to the local supreme people's court step-by-step, in an effort to avoid abusing of effect rules by the courts. In addition to that, standard for applicable effect rules shall be established. Over here, the author purports a simplified effect rule, namely, damages generated by infringement acts and directivity of such infringement acts. Damages triggered by acts, request that in a case, infringement acts take place outside one country cause damages to the residents inside this country, including losses in terms of economic benefits and mental losses. Losses caused by infringement acts against residents inside one country must be reflected via objective conditions. The people's court is not allowed to decide and purport jurisdiction of such case only based on the victim's statements, investigations and testimonies are most critical aspects for the people's court to consider. Directivity element of an act carries its judgment by investigating whether the involved objectives are resident inside the country or whether such objective possesses his/her primary business site inside the country. Please be noted, over here, what is pointed out by the author is "objectives involved in the acts" not "objectives referred to by the 
acts". The reason for the author to purport such broad-sensed directive standard is established on such a foundation that the people's court can appropriately measure losses suffered by the victim according to authentic situation. In other words, the people's court shall conduct strict measurements towards those loss-generating factors, whereas, more slackened standards can be adopted when measuring those directive factors. To sum up, only when both of these two factors are present for a case, can the people's court perform jurisdiction towards this case based on the effect rules. Lastly, the author not only advocates jurisdiction affirmation by the people's court against such cases, what is more important is, that stipulations shall be made in the judicial assistances enacted in the other countries and regions (including Hong Kong, Macao and Taiwan of China) to assert that the effect rules can be adopted by the courts as their basis in performing their jurisdictions, the other supporting judicial assistance related terms shall also be furnished, such as delivery of judicial documents, evidence obtaining from foreign countries, confession and execution of judgments, etc., in an effort to establish a comprehensive system for the courts to handle cases according to the effect rules.

\section{Conclusions}

Constructions of characteristic socialism legal system in our country are carrying on vigorously, construction of specialized legal system in our country does not stand for closed-door undertaking. As for legal systems within western countries such as Britain, America and France, we shall absorb their quintessence and desert their scum, in an effort o introduce their eminent legal system into our own, in order to make contributions for the characteristic socialism legal construction in our country. In this thesis, researches on American court cases and related work from the other scholars have been made and cited for the purpose of uncovering application results of adoption of effect rules into American judicial practices, in an effort to show more realities with respect to application of effect rules, so that references can be created for judicial practice in our own country.

\section{References}

A. Benjamin Spencer. (2006). Jurisdiction and the Internet: Returning to Traditional Principles to Analyze Network-Mediated Contacts. 2006 U. ILL. L. R EV. 71.

Alexand B. Punger. (2009). Mapping the World Wide Web; Using Calder V. Jones to Create a Framework For Analyzing When Statements Written On the Internet Give Rise to Personal Jurisdiction. 87 N.C.L. Rev.1952,*1953. September, 2009.

Andrew F. Halaby. You Won't Be Back: Making Sense of "Express Aiming” After Schwarzenegger v. Fred Martin Motor Co. 37 Ariz. St.L.J.625, ${ }^{*} 656$.

Calder v. Jones, 465 U.S. 783,790 (1984).

Cassandra·Burke-Robertson. The Inextricable Merits Problem in Personal Jurisdiction. 45 U.D.C.Rev.1310, 6*1311, 2012.

Imagline, Inc.v. Fotolia, LLC, 663F. Supp.2d 1367(N.D. Ga 2009).

Niloufer Selvadurai. the Proper Basis for Exercising Jurisdiction in Internet Disputes: Strengthening State Boundaries or Moving Towards Unification? Journal of Technology Law \& Policy, VOLUME XIII-Spring 2013, ISSN 1087-6995 (print). http://dx.doi.org/10.5195/tlp.2013.124

UBID, Inc.V.GoDaddy Group, Inc., 2010W1 3758075(7 $7^{\text {th }}$ Cir.Sept, 29, 1010).

Young v. New Haven Advocate, 315 F.3d 256,261 (4 $4^{\text {th }}$ Cir 2002). 